\title{
Development of a geotechnical and geophysical database for seismic zonation of the Ankara Basin, Turkey
}

\author{
Mustafa K. Koçkar · Haluk Akgün
}

Published online: 19 February 2008

(C) Springer-Verlag 2008

\section{Erratum to: Environ Geol}

\section{DOI 10.1007/s00254-007-0973-6}

Unfortunately, an error occurred in the author's affiliations.

The correct affiliations are given below:

Mustafa K. Koçkar (ه)

Gazi University,

Earthquake Research and Application Center,

Ankara 06500, Turkey

e-mail: mkockar@gazi.edu.tr

Haluk Akgün

Faculty of Engineering, Department of Geological

Engineering,

Middle East Technical University (METU),

Ankara 06531, Turkey

e-mail: hakgun@metu.edu.tr

The online version of the original article can be found under doi:10.1007/s00254-007-0973-6.

\section{K. Koçkar ( $\square)$}

Earthquake Research and Application Center,

Gazi University, Ankara 06500, Turkey

e-mail: mkockar@gazi.edu.tr

H. Akgün

Faculty of Engineering, Department of Geological Engineering,

Middle East Technical University (METU),

Ankara 06531, Turkey

e-mail: hakgun@metu.edu.tr 